2012s-30

\title{
Insurer Information, Insiders and Initial Public Offering
}

M. Martin Boyer

\begin{tabular}{c}
\hline Série Scientifique \\
Scientific Series
\end{tabular}

Montréal

Novembre 2012

(C) 2012 M. Martin Boyer. Tous droits réservés. All rights reserved. Reproduction partielle permise avec citation du document source, incluant la notice $($ ).

Short sections may be quoted without explicit permission, if full credit, including (C) notice, is given to the source.
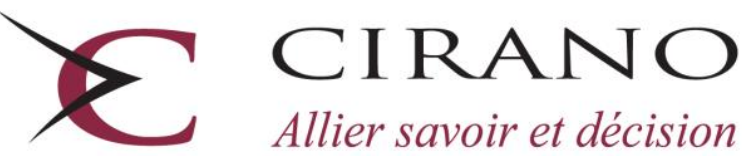

Allier savoir et décision

Centre interuniversitaire de recherche en analyse des organisations 


\section{CIRANO}

Le CIRANO est un organisme sans but lucratif constitué en vertu de la Loi des compagnies du Québec. Le financement de son infrastructure et de ses activités de recherche provient des cotisations de ses organisations-membres, d'une subvention d'infrastructure du Ministère du Développement économique et régional et de la Recherche, de même que des subventions et mandats obtenus par ses équipes de recherche.

CIRANO is a private non-profit organization incorporated under the Québec Companies Act. Its infrastructure and research activities are funded through fees paid by member organizations, an infrastructure grant from the Ministère du Développement économique et régional et de la Recherche, and grants and research mandates obtained by its research teams.

\section{Les partenaires du CIRANO}

\section{Partenaire majeur}

Ministère du Développement économique, de l'Innovation et de l'Exportation

\section{Partenaires corporatifs}

Autorité des marchés financiers

Banque de développement du Canada

Banque du Canada

Banque Laurentienne du Canada

Banque Nationale du Canada

Banque Royale du Canada

Banque Scotia

Bell Canada

BMO Groupe financier

Caisse de dépôt et placement du Québec

Fédération des caisses Desjardins du Québec

Financière Sun Life, Québec

Gaz Métro

Hydro-Québec

Industrie Canada

Investissements PSP

Ministère des Finances du Québec

Power Corporation du Canada

Rio Tinto Alcan

State Street Global Advisors

Transat A.T.

Ville de Montréal

\section{Partenaires universitaires}

École Polytechnique de Montréal

HEC Montréal

McGill University

Université Concordia

Université de Montréal

Université de Sherbrooke

Université du Québec

Université du Québec à Montréal

Université Laval

Le CIRANO collabore avec de nombreux centres et chaires de recherche universitaires dont on peut consulter la liste sur son site web.

Les cahiers de la série scientifique (CS) visent à rendre accessibles des résultats de recherche effectuée au CIRANO afin de susciter échanges et commentaires. Ces cahiers sont écrits dans le style des publications scientifiques. Les idées et les opinions émises sont sous l'unique responsabilité des auteurs et ne représentent pas nécessairement les positions du CIRANO ou de ses partenaires.

This paper presents research carried out at CIRANO and aims at encouraging discussion and comment. The observations and viewpoints expressed are the sole responsibility of the authors. They do not necessarily represent positions of CIRANO or its partners. 


\title{
Insurer Information, Insiders and Initial Public Offering
}

\author{
M. Martin Boyer*
}

\begin{abstract}
Résumé / Abstract
This paper develops and tests hypotheses regarding the relationship between D\&O insurance purchase and firm size, governance characteristics, and business risk, using a unique panel dataset on Canadian firms for years 1996-2005. The rich data permit examination of the determinants of insurance pricing, ownership, and coverage limits. The panel structure of the data also permits examination of the effects of insurance on corporate governance and earnings management. The paper adds to the literature by constructing empirical models motivated by theoretical considerations, controlling for firms' self-selection into insurance, and accounting for industry and year effects. Results provide strong statistical evidence for the view that D\&O insurance markets take corporate risk into account, but insurance reduces the deterrent effects of potential liability for mismanagement. The findings suggest that mandatory disclosure of $\mathrm{D} \& \mathrm{O}$ insurance, as required in Canada, is not sufficient to control the moral hazard effects of insurance ownership.
\end{abstract}

Mots clés/keyswords : Directors' and Officers' Insurance, Corporate Insurance and Risk Management, Board Compensation.

Keywords: G34, G22, J44, G32

*Department of Finance, HEC Montreal (Université de Montréal) and CIRANO, martin.boyer@hec.ca 


\section{Introduction}

Litigation against a firm's directors and officers is one of the unfortunate consequences of governance risk. As representatives of the corporation, directors and officers are personally liable $^{1}$ for damages caused by actions of the corporation or absence thereof. Having their personal wealth exposed to such an important liability risk induces directors and officers to request protection in the unlikely event a lawsuit is brought against them as representatives of the corporation. This insurance, known as directors' and officers' liability insurance (D\&O insurance hereinafter), is extremely common in public corporations. ${ }^{2}$

Baker and Griffith (2008) argue that shareholders are the most likely firm stakeholders to sue directors and officers, and that securities class action on the basis of misrepresentation are the most costly type of lawsuits (see also the different Towers-Watson surveys ${ }^{3}$ ). The threat of a class action lawsuit is so important that it prompts firms to invest significantly in reducing the potential cost of agency problems (see McTier and Wald, 2011). Provided insurers use the correct technology to transform a firm's observable characteristics into a D\&O liability insurance premium, the insurance contract should therefore provide information on the firm's financial

\footnotetext{
${ }^{1}$ A corporate director's duty goes beyond a simple firm value maximizing paradigm to include a fiduciary duty, a duty of loyalty and a duty of care.

${ }^{2}$ According to different Towers-Watson surveys (that were in the past published by Tillinghast TowersPerrin, and before that by Watson-Wyatt), approximately 95\% of public corporations in the United States and $75 \%$ of public corporations in Canada provide such insurance to their managers.

${ }^{3}$ According to these surveys, $20 \%$ of U.S. firms had at least one lawsuit brought against their directors in the previous ten years, of which half, and the most costly, arise from shareholders.
} 
perspectives, the quality of its management team and its "deep governance" features (i.e. its culture and character as highlighted in Baker and Griffith, 2007a). As a consequence, insurers have the appropriate incentives to correctly measure the expected cost of litigation against the insured firm's directors and officers, so that the structure of a D\&O insurance contract should be an unbiased measure of a firm's governance risk.

Unfortunately the basic characteristics of D\&O insurance contracts are not publicly available for most U.S. firms (see Griffith, 2006). That is why researchers such as Chalmers at al. (2002) and Kalchev (2004) rely on a one broker's private book of business to examine the economic significance of having such insurance. A second strategy (see Linck et al., 2009) is to use the 27 firms incorporated in the state of New York and the 12 S\&P firms that voluntarily disclosed the information to examine what seems to impact how much D\&O premiums each company pays. Unfortunately, these companies do not reveal how much coverage they purchased, thus limiting the quality of the signal associated with the premium paid. An alternative is to use excerpts from the Towers-Watson surveys, as in Cao and Narayanamoothy (2011) who use only two survey years (2001 and 2002), and Fier et al. (2010). A third approach is to use Canadian data ${ }^{4}$ as in Core (1997, 2000), Boyer (2003), Park Wynn (2008), Gillan and Panasian (2009), Li et al. (2011), Rees et al. (2011) and Boyer and Stern (2012). This is the approach I will also take since Canadian firms typically disclose their D\&O insurance coverage along with the premium paid.

\footnotetext{
${ }^{4}$ Disclosure of basic D\&O insurance information has become the norm in Canada. The earliest work on Canadian public data was done by Core (1997) who shows that the main determinants of the demand for $D \& O$ insurance are the firm's litigation risk and its cost of financial distress.
} 
Unlike most studies on D\&O insurance that examine large well established firms (the notable exceptions being Chalmers et al, 2002, and Boyer and Stern, 2012), I will focus on firms that just went public though an initial public offering (IPO). In the case of Chalmers et al. (2002) - the paper that is closest to the current one since they study the relationship between IPO underpricing and D\&O insurance coverage for 72 American firms that purchased D\&O insurance through the same broker - the authors find that firms with more coverage at the time of the IPO were more likely to be sued for mispricing.

In line with Chalmers et al. (2002), I limit my study to companies that went public through an initial public offering (IPO) to see whether basic D\&O insurance contract characteristics have any power in predicting the firm's stock market risk and returns. I also limit the study to the years between 1996 and 2006 because information in not easily available prior to 1996, whereas securities class action lawsuits were introduced in Canada only after $2005 .^{5}$ In contrast to Chalmers et al. (2002), my sample of firms includes some that opted for no insurance, thus reducing the potential bias involved in using only firms that purchased $D \& O$ insurance from one particular insurance broker.

Results will show that the higher is a firm's D\&O insurance premium per dollar of coverage (what is known as the rate-on-line in the insurance industry), the higher is the firm's stock market volatility and the lower is its stock market return in the first year after the IPO. In other

\footnotetext{
5 Prior to 2005, securities class action suits were virtually unheard of. The first "large" settlement occurred in September 2008. Since 2006, approximately 20 class action suits have been filed. Securities Docket webpage http://www.securitiesdocket.com/2008/09/14/dimitri-lascaris-and-siskinds-leadingthe-way-in-canada/ (last visited on 31 October 2011).
} 
words, firms that insurance companies deem riskier at the time of the IPO have a lower (higher) stock market return (volatility) in the first year post-IPO. This result suggests that D\&O insurers possess information that could be valuable to stock market participants.

My results are robust to many econometric specifications (simultaneous equations, treatment effects) and robustness checks. The predictive power of D\&O insurance disappears after the first year, suggesting that market participants eventually learn information that was only available to insurers at the time of the IPO. As this information gradually permeates the market, D\&O insurance does not seem to hold any predictive long-term power, at least with respect to the stock market return.

The use of $D \& O$ insurance information as a tool to predict stock return and volatility falls within the recent push to find a way to account properly for a firm's governance structure (see Rose, 2007, Bebchuk and Hamdani, 2009, Bebchuk and Weisbach, 2010, and Adams et al., 2010, inter alia). As many governance factors are not specified properly or are completely unavailable to the general investor (see Baker and Griffith, 2007a), one has to wonder how much of the internal structure of the firm remains unknown to market participants. That is why Holderness (1990), O'Sullivan (1997), Core (2000) and Boyer and Stern (2012) argue that D\&O insurance providers are more likely to be good firm monitors since they have a monetary incentive to price the contract properly. A counter point to this argument is provided by Baker and Griffith (2007b) who argue that insurers do not seem to act as corporate governance monitors.

The informational problems between managers and shareholders must be even greater in new firms and in firms that are becoming public. Not only is the information incomplete, but it is 
not even obvious what the directional impact between governance and performance is. Bhagat and Bolton (2008) suggest that governance indices generally suffer from important measurement errors, irrespective of the necessity to account for the endogeneous relationship between governance and performance (see also Wintoki et al., 2012). A case in point is the relationship between board independence and market performance. As Bebchuk and Weisbach (2010) argue, the relationship between board independence and performance is hard to find, perhaps because firms respond to a plethora of governance problems with an optimal albeit constrained governance structure (see Adams et al., 2010). Measurement problems become arguably more important when looking at IPOs since relatively little is publicly known about the firm's past financial stability and health.

The remainder of the paper is organized as follows. Section 2 presents a short primer on directors and officers insurance contracts. I develop my hypotheses and describe the data in Section 3, and present the main results of the paper in Section 4 . Section 5 is devoted to robustness checks. Finally, Section 6 concludes with a discussion.

\section{Directors' and officers' insurance: A primer}

\subsection{D\&O insurance contracts}

Directors' and officers' liability insurance contracts cover corporate directors and officers against lawsuits brought against them as representatives of the corporation. Divergence in interests mixed with asymmetric information between managers (including both directors and officers) and shareholders is the main source of conflicts, and potentially the most costly. The 
insurance company will reimburse the corporation and/or its managers for the costs of settling and defending the lawsuit up to the policy limit, provided the firm's directors and officers have acted honestly and in good faith. In theory, should managers and their company have acted in a fraudulent manner, the insurance company could decide not to honor the policy.

A D\&O insurance policy is usually comprised of three distinct types of coverage. Side $A$ coverage covers directors and officers directly whenever their corporation is unable or unwilling to indemnify them. Side $A$ has no deductible and is usually purchased by a corporation on behalf of their directors to attract competent outside directors. Side $B$ coverage reimburses the corporation whenever it indemnifies its managers following a lawsuit brought upon them as a representative of the corporation. Side $C$ coverage reimburses claims made against the company itself, typically concerning securities claims. Hence, Side $B$ and Side $C$ cover the corporation rather than its directors and officers thereby epitomizing agency costs, as mentioned by Griffith (2006). The 2006 Towers-Watson survey mentions that $38 \%$ of public companies purchased Side A only coverage, and that this figure is on the rise. Clearly directors are increasingly aware of the risks they face when they take on the position.

\subsection{The pricing of D\&O coverage}

Insurance companies must accurately assess the potential cost of each policyholder since they ultimately bare the full cost of any mistake. As a result, D\&O insurance underwriters have developed specific risk assessment tools that allow them to properly select clients and their litigation risk - there are no bad risks, just badly priced risks. Underwriters use three sources of information: The written application that contains a full array of documentation, the analysis of 
public financial and accounting data, and interviews with the prospective insured's senior management team. ${ }^{6}$ This underwriting procedure means that very little asymmetric information remains between the underwriter and the insured. ${ }^{7}$ The information gathered by the insurer about a potentially insured firm's internal processes and structure is not divulged to other market participants.

Baker and Griffith (2007a) present one approach used to measure a firm's potential cost of litigation that is based on the firm's financial information, the industry's perspective and the firm's governance risk factors. Of particular interest is the fact that insurers appear to divide the analysis of governance characteristics into two categories: Culture, which refers to the stringency of the firm's formal and informal internal controls (how the information is disseminated in the firm), and Character, which refers to the directors' and officers' attitude toward risk. In essence, Culture seeks to identify the source of potential D\&O litigation whereas Character aims to uncovering the managers' sense of ethics. Consequently, as in the pricing ${ }^{8}$ of

${ }^{6}$ Baker and Griffith (2007a) provide a valuable in-depth account of the pricing approach used by D\&O underwriters using detailed interviews of 41 D\&O insurance professionals (underwriters, actuaries, brokers, risk managers, lawyers and claim process specialists). They also report that, in the United States, the average settlement was $\$ 13.3$ million for the period 1996-2001, $\$ 22.3$ million for the period 20022005 and $\$ 33$ million in 2006-2007.

${ }^{7}$ See Knepper and Bailey (1998) and Baker and Griffith (2007a) for more details on the underwriting and auditing process of insurers. The moral hazard hypothesis that is often linked to having insurance was disproved by Bhagat, Brickley and Coles (1987) who find that the decision to purchase D\&O insurance does not reduce shareholder wealth.

${ }^{8}$ Core (2000) notes that the D\&O insurance premium paid is a function of the firm's governance structure quality, which he measures as the firm's ownership structure, board independence, management entrenchment and business risk. 
any insurance contract, insurers must assess properly the probability that a claim will be paid as well as the severity of such a claim. In the case of D\&O insurance, the probability and severity of a claim is likely linked to the firm's stock market performance since the most costly lawsuit are brought against the firms' managers by shareholders.

\section{Hypothesis development, data and variables description}

\subsection{Hypothesis and data}

The main hypothesis I develop in this paper is that firms that are riskier in the eyes of D\&O insurance providers have a post-IPO stock return that is lower and more volatile. Underpinning this question is my assertion that sellers of D\&O insurance use a plethora of publicly unavailable information from which a premium emerges, just like a credit score. As a result, D\&O insurance information should be valuable to investors.

The risk assessment conducted by $D \& O$ insurers is partly based on private information regarding the inner working and the governance quality of the firms that seek to protect their managers against the cost of lawsuits. Clearly if such information was to reach the stock market, it should be embedded directly and immediately in prices.

The D\&O insurers' risk underwriting technology is insurer specific and is not publicly known. And because they are usually absent from the offering prospectus, $D \& O$ insurance coverage and premium are not known at the time of the IPO, even though they are revealed later in the life of the firm. My null hypothesis will therefore be that D\&O insurance contract parameters have no power in explaining future risk and returns. The alternate hypothesis will be that D\&O insurance 
contract parameters have some ability to forecast a firm's stock market risk and returns in the first year of public life post-IPO. Figure 1 provides a timeline of D\&O insurance information.

\section{Figure 1. Timeline of the D\&O insurance information acquisition and release}

Firm operates as a private enterprise

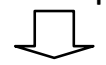

D\&O insurance purchased or not (no public information) as a private enterprise (the insurer conducts an audit and negotiates with the firm the coverage and premium)

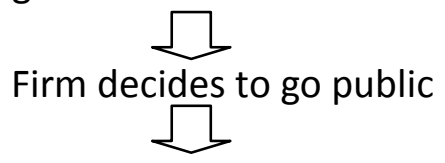

Firm contacts investment banker AND D\&O insurance purchased or not (no public information) as a "new" public firm. The Offering prospectus that includes a pro-forma annual statement, the date of the IPO and the offering price, is made public.

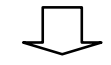

IPO occurs<smiles>C1CC2CCC2C1</smiles>

End of fiscal year (not necessarily 12 months after the IPO)

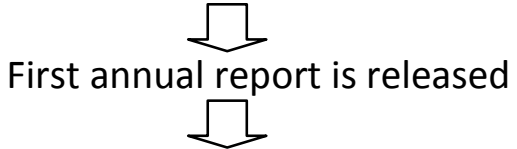

First management proxy is released (first public information about D\&O insurance, if any)

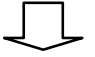

End of second year of operations

The main variable I shall use to measure an insurer's assessment of a firm's D\&O liability risk will be the "rate-on-line", which is essentially the ratio of the total premium paid to the maximum possible coverage (or the policy limit). I present the main testable hypothesis below.

$\mathbf{H 1}_{\mathbf{0}}$ : A firm's D\&O insurance rate-on-line at the time of the IPO has no power in explaining the firm's first year's stock market risk and return.

$\mathbf{H} \mathbf{1}_{\mathrm{A}}$ : A firm's D\&O insurance rate-on-line at the time of the IPO is linked to higher stock market volatility and lower return in the first year of trading. 
Because firms that pay a high premium per dollar of coverage are more susceptible to file a claim, their stock market return in the first year post-IPO should be lower and more volatile. ${ }^{9}$ If a D\&O insurance contract's rate-on-line conveys information, then a corollary to hypothesis $\mathbf{H} \mathbf{1}_{\mathrm{A}}$ should be that the firm's stock market performance much after the information is revealed should be uncorrelated with such information. The information gathered by insurers to form an opinion regarding the liability risk of an IPO firm before the IPO date becomes known to market participants some time after the first year post-IPO. This information should then be incorporated in the stock prices so that D\&O insurance information should not have any longterm predictive power.

H2 $\mathbf{2}_{\mathbf{0}}$ : A firm's D\&O insurance rate-on-line at the time of the IPO has no power in explaining returns after the first year.

$\mathbf{H} \mathbf{2}_{\mathrm{A}}$ : A firm's D\&O insurance rate-on-line at the time of the IPO is linked to lower return in the second year of trading.

\footnotetext{
${ }^{9}$ Boyer and Tennyson (2008) argue that similar to any insurance contract, D\&O insurance premiums depend on the frequency as well as on the severity of claims, as well as a cost of risk and other expenses. Assuming that premiums are the product of frequency $(f)$, severity $(s)$ and a proportional loading factor $(\mathrm{m})$, and that severity can be measured by the policy limit, we have that the rate-on-line (the ratio of premium to policy limit) is a good proxy for the frequency of lawsuits. To see why, let $P=f^{*} s^{*} m$ so that $P / S=f^{*} m$. If the loading factor is the same for all firms, then it will be picked-up in the regression constant when we use the log of the rate-on-line as an independent variable. Given that the different TowersWatson surveys report that lawsuits are more likely to occur (and more severe) following a decrease in the stock price, we have that the $D \& O$ insurance market is efficient if the premium-to-coverage ratio is a function of the likelihood that the stock price will decline.
} 
My results will show strong support for rejecting hypothesis $\mathbf{H} \mathbf{1}_{\mathbf{0}}$ in favor of hypothesis $\mathbf{H} \mathbf{1}_{\mathbf{A}}$, but no support for rejecting hypothesis $\mathbf{H} \mathbf{2}_{\mathbf{0}}$. Consequently, I will conclude that basic D\&O insurance contract parameters have some power to predict stock market returns in the first year of life post-IPO, but not in the second year.

To gather data to test my hypotheses, I use the same approach as in Huson and Pazzaglia (2007). Starting with the 1400-odd new securities issued in Canada over the period 1995-2005, we are left with only 272 Canadian firms that correspond to the classic definition of an IPO for the period 1995 through 2005 (see Huson and Pazzaglia, 2007, for more details). Financial data was collected from Compustat (when available) and from the firms' annual reports that were available on SEDAR, the Canadian equivalent of EDGAR. Due to missing data, my usable sample consists of 180 observations for which a decent number of financial and governance information is available. The main reasons why the number of firms drops from 272 to 180 is that many firms' first proxy circular or annual reports are not available on SEDAR. It is also often the case that information about the governance structure of the entity is not obvious, especially in terms of the board composition (who the chairman is, who is an independent director, etc). Moreover the intersection of missing information from the annual report and from the management proxy is such that if we want to use a firm's assets, market value of equity, total liability, board composition and independence, the number of usable observations drops to 150.

The financial variables collected are as of the end of the first fiscal year post-IPO. The governance and insurance information is collected in the first available management proxy and 
information circular. All monetary figures are in Canadian dollars and a conversion to Canadian dollars as of the end of the firm's fiscal year was applied when needed.

\subsection{Description of variables}

I describe the variables used in this paper below. I start with the dependent variables, the main independent variables and finish with all the control variables that I will use.

\subsubsection{Dependent variables}

The dependent variables I shall use reflect the firm's observed stock market risk and return following the IPO date. Starting with my main risk measure, the Volatility variable is calculated as the standard deviation of annualized daily returns. I expect firms that are deemed riskier by insurers, and that thus pay a higher rate-on-line, to have higher stock market volatility.

In terms of returns, I will use four different measures: The First year return, the First year excess return, the Two-year return and the Second year return. In all cases, if D\&O insurance providers have private information regarding the operations and governance of insured firms, firms that have a higher risk assessment measure should have a lower return.

First year return is calculated as the total return in the first year after the IPO's completion date. First year excess return is the one year total return the firm post-IPO minus the return on the S\&P/TSX, Canada's main stock market index, over the same period. If insurers are able to charge a higher premium to firms that will perform poorly because of their revealed poor governance and opaque operations, then the relationship between the first year's return, 
calculated either as First year return or First year excess return, and my measure of D\&O insurance risk will be negative. The Two-year return and the Second year return measures will also be used to see if $D \& O$ insurers are able to predict for a period longer than a year. The first is calculated as the total compounded stock return of the firms over a two-year horizon after the IPO completion date, whereas the second is calculated as the two-year compounded return minus the first year return.

I will also combine the risk and return variables by calculating two quasi-Sharpe ratio variables, called Sharpe ratio and Excess Sharpe ratio. In the first case, I divide First year return by Volatility, whereas I divide First year excess return by Volatility in the second measure. If the rate-on-line leads to higher volatility and lower returns, it should also lead to a lower quasiSharpe ratio value.

IPO issue price were collected using the firms' prospectus available on SEDAR. Values were verified using the FPInfomart database. Subsequent price information comes from Bloomberg.

\subsubsection{Main Independent variables}

The main variable of interest in this paper is the ratio of the total premium paid to the maximum possible coverage (or the policy limit). This information is usually released in the first management proxy after the firm becomes public. As D\&O insurance is considered part of managerial compensation, the information that is released relates to the previous year's protection (just as salary information relates to the previous year's compensation). This rate-online measure is modified in two ways in the paper to make it more tractable. First, I will use the 
log of ratio of the $D \& O$ premium to one thousand dollars of coverage $\left(L n_{-} R O L\right)$ to reduce the impact of very large rate-on-line on the results. Second, I will use the D\&O premium divided by 1000 dollars of coverage (Rate-on-line). In both cases a firm that pays a higher rate-on-line is hypothesized to be perceived by the insurer as riskier since it is paying more per unit of coverage. I will therefore test whether the rate-on-line has an impact on stock market volatility and returns (as well as the quasi-Sharpe ratios) in the first year of operations post IPO.

The decision to purchase insurance or not will be used in the first step regression equation of the Heckman two-step procedure to account for the possible selection bias that the sample of firms for which we observe the rate-on-line is not random. In other words, we need to account for the fact that we do not observe the rate-on-line for firms that choose to remain uninsured. Purchase is thus an indicator variable equal to one if the firm reported that it carried D\&O insurance in its first management proxy following its first annual report post-IPO, and zero otherwise. $^{10}$

\subsubsection{Control variables ${ }^{11}$}

I divide the control variables in three categories: Financial, Governance and Other. Each variable is presented in turn.

\footnotetext{
${ }^{10}$ As in Core (1997), Park Wynn (2008), Lin et al. (2011) and Boyer and Stern (2012), I shall assume that the lack D\&O insurance information disclosure in a firm's proxy circular means that the firm is uninsured. 11 Unless notes otherwise, all independent variables are measured using accounting information available in the firm's first annual report post IPO.
} 


\subsubsection{Financial variables}

Mkt1year is the one-year post-IPO return of the stock market as calculated by the total return of Canada's main stock index. I use FirstDayReturn as a control variable to account for the possible underpricing of IPO shares on the first day of trading to attract risk-averse investors (for a more thorough discussion, see amongst many others Ritter, 1987). This variable is computed as the price at the end of the first day divided by the offer price. Another motivation for using FirstDayReturn as a control variable is that Chalmers et al. (2002) find a significant negative relationship between D\&O insurance coverage and IPO underpricing, suggesting that IPO underpricing acts as a substitute for shareholder lawsuits. If true, this means that there exists a negative relationship between D\&O insurance coverage (the denominator of the rateon-line) and the one-day return. It is therefore important to control for the first-day return in the regression.

I will measure firm size by the log of the firm's market value of equity at the time of the IPO (InMVE_IPO). Large firms should be less volatile and, possibly, more successful on average because more investors will scrutinize the activities of larger firms. I use a firm's market value of equity at the time of the IPO to guarantee that this measure of size is not too much confounded with stock market returns. The InMVE_IPO variable is calculated as the log of the product of the offer price by the number of shares outstanding on the day of the IPO.

Growth measures a firm's growth opportunities. Following Core (1997), I compute Growth as $\frac{\text { market value of equity at time of IPO }+ \text { book value of liabilitie } s}{\text { book value of assets }}$. A firm with a high growth 
ratio should be more profitable if the growth options turn out to be in the money. Consequently, we should expect high growth firms to have higher first year returns on average. The last financial variable I will use is the firm's book leverage (or Debt_Ratio), which I calculate as $\frac{\text { Total Liabilitie s }}{\text { Total Assets }}$. Stock market volatility should be lower if debt holders are exercising a greater level of monitoring. On the other hand, the more levered is the firm the higher should be its stock return volatility since it is more at risk of going bankrupt. The overall effect is confounded.

\subsubsection{Governance variables}

I collected several variables related to governance: CEO and chairman of the board duality, board composition and independence, the presence of a blockholder. I will also control for the corporate structure.

Duality is an indicator variable taking on the value one if the chairman of the board is also the company's chief executive officer and zero otherwise. This particular feature of a board is usually viewed as an entrenchment red flag. If entrenchment is an issue then Duality could be associated with low volatility (because the CEO/COB does not want to risk bankruptcy) and low return (because firm resources are spent on projects that are not necessarily value creating). Because Duality affects both risk and return in the same direction, I do not expect to see much impact on the Sharpe ratio variables.

Blockholder is an indicator variable equal to one if a shareholder owns $10 \%$ or more of the firm's voting shares according to its first proxy statement. Similar to debt holders, block holders 
should have more at stake in monitoring the firm. Consequently, stock return volatility should be lower when a block holder is present.

Independence is the percentage of unrelated directors on the board of directors as mentioned in the firms' proxy statements. The presence of a more independent board could increase returns if it prevents the entrenchment of management and if it reduces the likelihood of cash flow misappropriation.

The ITCE variable is an indicator variable equal to one if the company is an income trust and zero otherwise. I include this variable since Halpern (2004), Gillen (2005), Zetzsche (2005) and Huson and Pazzaglia (2007) argue that is that income trusts are riskier than stock companies from a governance standpoint (see also Boyer and Stern, 2012). The greater governance risk of income trusts is not only due to their higher risk of cash flow misappropriation, but also due to a lack of jurisprudence regarding their directors' and officers' duties. On the other hand, income trusts are required to pass along more of their operating cash flows to their investors, which should reduce volatility and returns since very little earnings are reinvested, which makes capital gains infrequent. Volatility should be lower since income trusts distribute more dividends, and are older and more mature firms than stock companies. The impact of ITCE on Sharpe is therefore confounding since the numerator and the denominator are expected to decrease when the firm is an income trust. 


\subsubsection{Other variables}

Risky_Industry is an indicator variable equal to one if the firm belongs to one of the ten twodigit SIC codes risky industries as identified in Bajaj et al. (2000). Firms that belong to one of these ten risky industries, that were deemed riskier based on the number of cases settled as well as the average settlement amount, should have more volatile stock returns and, possibly, higher returns on average. Firms operating in risky industries should also be more likely to purchase D\&O insurance if only because of the higher frequency of lawsuits.

Age measures the number of years since the start of the company's operations at the time of the IPO announcement. I expect this variable to have a negative coefficient impact on stock market volatility since the firms becoming public should be more mature and have more stable cash flows, everything else equal.

The service offered by the investment banker at the time of the IPO is represented by the variable IPOfeerat, which is calculated as the total fees paid at the time of the IPO divided by the market value of the IPO (offer price multiplied by number of shares outstanding). I expect firms that purchase a higher level of service to have higher returns in the first year and lower volatility.

Float is the ratio of the number of shares issued at the IPO on the total number of shares outstanding after the IPO. I expect that firms that have a higher float should have less volatile market returns because more investors are likely to follow the firm, therefore disseminating the appropriate information to the markets. With respect to the decision to purchase D\&O 
insurance or not, Float should be positively correlated with the decision to purchase. The reason is that the more shares are issued, the greater the probability of litigation and the greater should be the expected loss should a claim arise (see Guttiérrez, 2003, and Boyer, 2003) since minority shareholders are the most likely originator of lawsuits against managers. At the same time, a greater float means that the "firm's entrepreneur" has gotten rid of a larger portion of the firm, which should be a bad signal to markets. If such adverse selection is present, stock return should be negatively related to the float. And because a higher float means that more different market participants are interested in the firm's activities, information should be more reliable all the time so that stock market volatility should be smaller.

US_Presence is a dummy variable equal to one if the firm reports activities in the United States. The variable was collected by looking at annual reports for the year following the IPO. The United States being a more fertile environment for potential litigation, I expect this variable to be positively correlated with the decision to purchase $D \& O$ insurance. A related measure to US_Presence is US_Sales that is measured as the ratio of sales that a firm reports doing in the United States to total sales. Sales in the United States should increase stock returns since it is a proxy for the potential growth in sales and profitability of the company.

\subsection{Sample Statistics}

Table I presents the number of IPOs by year over the sample period. The first line presents the number of IPOs that were initiated in that year (1995-2005), whereas the second line presents the number of IPOs that were completed in that year (1995-2006). The third line gives us the year when the first management proxy circular is available (1996-2006). 
[INSERT TABLE I ABOUT HERE]

Table II presents the main sample statistics of the variables that I will use in this paper, starting with the dependent variables, the variables related to the D\&O insurance contract and finishing with the different control variables and the variables used in the treatment equation related to the decision to purchase D\&O insurance. Dichotomous variables in Table II are those for which the entire sample statistic is not provided.

[INSERT TABLE II ABOUT HERE]

It is interesting to note that of the average return in the first year is $11.5 \%$, giving an average excess return in the first year of $3.4 \%$, whereas the median return is only $7.5 \%$ with a median excess return of $-3.0 \%$. Eight companies did not reach the end of the first year of operations, and 2 companies did not trade on their first day post-IPO (for the other 15 companies for which no initial day return is available, the data is not available for the 3 and 12 companies that completed their IPO in 1995 and 1996 respectively). The two-year return is more than twice the return in the first year; only one company ceased its operations in the second year.

In terms of the main variables of interest, we see that information about the Rate-on-line is available for only 103 firms out of the original 180. Of the 77 firms for which no rate-on-line is available, 54 are deemed not to have purchased D\&O insurance whereas the other 23 purchased D\&O insurance but did not give enough details to calculate the rate-on-line (typically, the premium information is not revealed). These 23 firms must be kept in the dataset regressions because the mere fact that they purchased insurance tells us something about their 
behavior toward insurance. In the end, I therefore have 126 out of the 180 companies (70\%) in my usable sample that purchased D\&O insurance to protect their directors and officers. The proportion of D\&O insurance purchasers in my usable sample is similar to that published in the different Towers-Watson surveys in relation to the entire Canadian market.

\section{Analysis of results}

The theoretical econometric model has the following structure.

1- Firms decide to go public through an initial public offering;

2- Firms decide to purchase D\&O insurance or not

3- Insurers give firms that purchase D\&O insurance a price per unit of coverage (rate-online);

4- The stock market reacts to the flow of information during the year.

The variables that determine whether a firm goes public (step 1) are, of course, not measurable since we do not have access to information for non public firms. After deciding to go public, a firm purchases a D\&O insurance contract (or not) in step 2. Regarding step 3, we observe a firm's rate-on-line only if it purchased insurance. To control for the potential selection bias in steps 2 and 3, I shall use a classic Heckman two-step procedure as we will see in later sections of the paper (but there does not seem to be any selection bias in the data). Step 4 is potentially given by a system of equations that gives us risk and return simultaneously. 


\subsection{Preliminary results}

Panel A of Table III separates the observations presented in Table II between firms that have D\&O insurance and firms that do not, and offers some descriptive statistics. Of the $70 \%$ of IPO firms revealing having purchased D\&O insurance around their IPO date, the average premiums was $\$ 148,554$ for an average coverage of $\$ 24$ million. We also see a very wide distribution for the rate-on-line variable, which is reported as the premium paid per $\$ 1000$ of coverage. We see that the maximum rate-on-line is almost 40 times larger than the minimum rate-on-line. The average rate-on-line on line is $\$ 7,227$ per $\$ 1,000$ of coverage, whereas the median rate-on-line is $\$ 6,370$ per $\$ 1,000$ of coverage. This provides some justification for using a log-transformation of the rate-on-line.

[INSERT PANel A of TABle III ABout here]

When examining the decision to purchase insurance (the Purchase variable is equal to one if the firm revealed carrying D\&O insurance around its IPO and zero otherwise), the hypothesis is that this decision should be influenced by financial, governance measure and other control variables. Panel B of Table III shows the results of a simple probit model on the decision to purchase D\&O insurance for different model specifications or not.

\section{[INSERT PANel B of TABLE III ABOUt here]}

These results are quite consistent across all model specifications. Of all the financial and governance measures, only Debt_Ratio seems to have a significant impact on the purchase of D\&O insurance across all model specifications. Specification 1 includes all the financial and 
governance variables we have in the regression, whereas Specification 2 includes only those that were significant in the univariate analysis of Panel A (except US_Sales). Interestingly, only in Specification 2 is US_Presence significant in explaining the purchase of D\&O insurance, in contrast to what was found for larger firms in Rees et al. (2011). Firm size, as measured by the log of the firm's market value of equity (InMVE_IPO), seems to have no impact on the decision to purchase $D \& O$ insurance. This is contrary to most studies that examine the demand for $D \& O$ insurance (see Core, 1997, and Boyer, 2003). Perhaps the demand for D\&O insurance by new firms that are going public through an IPO is driven by factors that are slightly different that the demand for D\&O insurance by more mature and established firms.

Specification 3 uses only the governance measures to see if $D \& O$ insurance is a substitute or a complement to other governance measures. In particular, Independence does not seem to increase the likelihood of having D\&O insurance, contrary to what has been the main argument provided to support the existence of this type of insurance contract (see Bhagat et al., 1987).

Concentrating now on Specification 4, that adds whether the firm announced in its IPO prospectus that it had D\&O insurance (DO_Prospectus) to the variables used in Specification 2 (i.e., only the variables that were significant in explaining the purchase or not of D\&O insurance in an univariate regression), we observe again that only the firm's debt ratio has a significant impact on the likelihood of having D\&O insurance in the first year after the IPO. Surprisingly, whether the firm has activities in the United States (US_Presence), which is significant in Specification 2, no longer seems significant after controlling for other factors. The positive and significant impact of the DO_Prospectus variable suggests that there is some sort of inertia in 
the purchase of D\&O insurance as the most likely reason for a firm to purchase $D \& O$ insurance in the current year is whether it purchased D\&O insurance in the previous year (see Kalchev, 2004, and Boyer and Tennyson, 2008, for discussions of this phenomenon). We will control later (in Table IX) for the inertia associated with the D\&O insurance information included in the prospectus. We shall see that the paper's main results are sensibly the same. Specification 4 will be the model used later as the Heckman's selection regression (first stage) model.

\subsection{The Short-term Predictive Power of D\&O Insurance}

We report in the five panels of Table IV the results from OLS regressions where we examine the impact of the main independent variables (the log of the rate-on-line or the premium per $\$ 1,000$ of coverage) on five different risk and return measures. All regressions also control for a set of measures that have been hypothesized to have an impact on the risk and return of a firm in the first year after the IPO. Panel A presents the results using the first year total return as the dependent variable, Panel B uses the market-adjusted first year return (i.e., the difference between the firm's stock return and the market return), Panel C uses the volatility of the firm's stock return in the first year, Panel D with respect to the quasi-Sharpe ratio (i.e., the ratio of the first year total return to volatility) and Panel E with respect to the market-adjusted quasi-Sharpe ratio (i.e., the ratio of the first year market-adjusted return to volatility).

[INSERT PANel A of TABle IV ABOUt here]

[INSERT PANEL B OF TABLE IV ABOUt HERE]

[INSERT PANel C OF TABle IV ABOUt here] 
[INSERT PANel D of TABle IV ABOUt here]

[INSERT PANEL E OF TABLE IV ABOUt HERE]

The story in all five panels is generally consistent with the hypothesis that D\&O liability insurers have information at the time of the IPO that should be valuable to stock market participants. We see that the price per unit of D\&O insurance coverage (whether it is the log of the rate-on-line or simply the premium-to-coverage ratio) is significantly related to the firm's stock market return (in Panels $A$ and $B$ ), risk (in Panel C) and return per unit of risk (Panels D and E) in the first year after the IPO. ${ }^{12}$ These results support the idea that the technology used by D\&O insurers to transform into premiums the firms' liability risk characteristics has some power in explaining the firms' first year basic stock market return characteristics.

Interestingly, very few control variables have any statistical power in explaining the return, the risk and the return per unit of risk of newly public firms. For instance in Panel A and Panel B, where we try to explain the first-year return (Panel A) as well as the market-adjusted first year return (Panel B), no firm specific characteristic has any significant impact that is robust to all econometric specification. Results with respect to the return per unit of risk (the quasi-Sharpe ratio in Panel $D$ and the excess quasi-Sharpe ratio in Panel E) have similar features. The only explanatory power that firm-specific variables have is in explaining the first year's stock market volatility (Panel C).

${ }^{12}$ The number of observations used in Specification 1 of each panel is higher than in the other regressions because it includes all firms for which we have accounting and governance information whereas the four other regressions in each panel include only those firms that purchased D\&O insurance and for which we have the premium as well as the coverage. 
The results presented in the first five panels of Table IV use the information that is available at the time of the IPO. One could argue that all that information is already incorporated in the stock price at the time of the IPO by the investment banker, or that it is quickly reflected in the stock price at the end of the first day. As a consequence, it is normal to observe little impact of known firm specific characteristics on the stock return in the first year. Panel $F$ and Panel $G$ of Table IV present regression results using only the information that is unknown to investors at the time of the IPO: The rate-on-line, the market portfolio return in the first year and the first day's return. Panel $\mathrm{F}$ includes year fixed effects in the regression whereas Panel $\mathrm{G}$ does not.

[INSERT PANel F of TABLe IV about here]

[INSERT PANel G of TABle IV about here]

We see in these two panels that the paper's main hypothesis, that the rate-on-line conveys valuable information, is supported since returns (both total and in excess of the market) and returns per unit of risk (both total and in excess of the market) are negatively affected by either measure of the rate-on-line. Although the results for the stock return volatility are not as strong, the rate-on-line still has some predictive power when year fixed effects are included. 


\subsection{Long-term impact}

I present in Table $\mathrm{V}$ regression results for the two-year compounded stock market return and the second year return. ${ }^{13}$ The number of observations is, of course, smaller since some firms have disappeared in the second year because of merger activities or bankruptcy.

\section{[Insert Panel A of TAble V about here]}

In every specification the long-run return is not linked to either measures of D\&O insurance rate-on-line. Only the total stock return over the first year appears to have a significant and persistent impact on the two-year compounded return, which should happen by construction as the return over the first year is included in the two-year compounded return. Focusing on the second year return only (i.e., the two-year compounded return minus the first year's return), Specifications 5 and 6 show that the rate-on-line measures remain insignificant in explaining the long-run return in all model specifications. That being said, it seems that Growth has some significant negative impact on long-run returns, although it had no explanatory power in the first year. The results in Table $V$ are consistent with our hypothesis that when the D\&O insurance information becomes public sometime after the first year of trading, that information is somehow incorporated in the prices so that returns in the second and third year are no longer dependent on the information related to the first year of operations. We can therefore conclude that $\mathrm{H}_{2}$ cannot be rejected so that there is no evidence that $\mathrm{D} \& \mathrm{O}$ insurance information has any long-term impact on stock prices.

\footnotetext{
${ }^{13}$ The analysis using the three-year compounded and the third year return yielded similar results.
} 


\section{$5 \quad$ Robustness checks}

This section reports the results of a series of robustness tests that examine the sensitivity of the empirical results to various econometric specifications. As we will see, the results presented in this section are generally the same as those I presented in the different panels of Table IV.

The first robustness check I conduct is to see whether the choice of being insured or not creates a significant selection bias in the sense that firms that choose to purchase insurance are fundamentally different from those that do not. I will control for the potential selection bias using a classic Heckman two-step approach in all the panels of Table VI.

The results of Table VII take into account the potential simultaneous determination of risk and return in the model since feedback effects could exist between volatility and return. Using a three-stage least square approach to account for such simultaneity does not alter the results much; if anything, the results appear stronger. Table VIII combines the selection bias and the feedback effect by including the inverse-Mills ratio in the three-stage least square regression. Again, the results remain unchanged.

The last set of results I present in Table IX includes only the firms that did not provide enough information in their IPO prospectus to calculate a rate-on-line. Despite a further reduction in the number of observations, the main message of the paper holds: D\&O insurance appears to have some predictive power regarding the return in the first year of operations post-IPO.

We can therefore be quite confident that the paper's main results presented in the different panels of Table IV are robust. Consequently, there is ample evidence to suggest that the firms's 
first year returns are significantly predicted by the price per unit of coverage of D\&O insurance, suggesting that insurers that offer directors and officers protection against liability lawsuits brought against them as firm representatives know something at the time of the IPO that investors should find valuable: An audit of the firm's governance risk.

\subsection{Likelihood of carrying D\&O insurance and two-step regression}

It is possible that the decision to purchase $D \& O$ insurance conveys information to the market that is not captured when we are only using an OLS regression of the rate-on-line to explain the first years' risk and return. Indeed, given that we do not observe the rate-on-line of firms that do not purchase insurance the distribution of insured and non-insured firms is not random and could therefore bias the results.

I shall use a Heckman (1979) two step approach to reduce the potential bias. The first step consists of a probit regression that assesses the determinants that induces a firm to purchase D\&O insurance around its IPO date. Similar to the regression results I presented in Panel B of Table III, the dependent variable in this regression is Purchase. I will model the firms' decision to purchase insurance using Specification 4 in Panel B of Table III. The second step in the Heckman two-step procedure involves an OLS regression to determine what impact the two rate-on-line measures have on the different post-IPO dependent variables. Table VI presents the regressions results for different model specifications. Panel A presents the two-step analysis results for the

first year total and excess stock returns whereas Panel B presents the results for the volatility and the quasi-Sharpe ratio. 
[INSERT PANel A of TABle VI about here]

[INSERT PANel B OF TABLE VI ABOUt heRe]

Starting with the first stage results (under the different "Purchase" columns) we see that only whether the firm had announced in its prospectus that it carried D\&O insurance have any impact on the whether the company said it had D\&O insurance in its first proxy statement. No other firm specific variable ${ }^{14}$ seems to have any explanatory power.

With respect to the second stage regressions, we see in Panel A (first year total and excess stock returns) that the two main variables of interest, the log of the rate-on-line and the premium per $\$ 1,000$ of coverage, have a negative significant impact on the total return of firms that went public through an initial public offering. Not only do the selection bias regression results confirm the results presented in Table IV, even the value of the coefficients are extremely similar. Indeed, comparing the results of Specifications 1 and 2 of Panel A of Table VI to the results of Specifications 5 and 7 of Panel A of table IV, we see that the economic size of the coefficients remains almost the same after controlling for the potential selection bias. This should tell us that the impact of the selection bias is quite small, at least with respect to the first year's return.

With respect to Volatility in Panel B (Specifications 1 and 2), we see again that the two main variables of interest have an impact that is in line with the paper's main hypothesis: The

\footnotetext{
${ }^{14}$ The results vary a little from specification to specification because of the preferred use of a Maximum Likelihood Estimator econometric approach instead of a two-stage least square regression.
} 
insurance premium per unit of coverage is positively linked to the volatility of the stock price in the first year post-IPO. This means that insurance companies that provide firm managers with protection in the event of a lawsuit brought against them as representatives of the corporation seem to have a technology that allows them to predict the volatility of the stock price in the year following the IPO. If one believes that stock price volatility is, inter alia, the result of governance opaqueness, the results presented in Panel B of Table VI suggest that insurers are able to assess such opaqueness when they insure the firms' managers.

In terms of the other control variables, we observe that firm size at the time of the IPO (InMVE_IPO) is negatively related to stock price volatility, and so is the income trust structure (ITCE) compared to the stock company. The first result is in line with the perception that larger firms should have a larger number of analysts following them so that stock price volatility should be smaller. With respect to income trusts, the Volatility results suggest that because income trust are mandated to distribute more to unit holders, they require stable cash flows to exist. In both cases the results are in line with our hypotheses. Interestingly, firms that have a larger proportion of their stock issued at the time of the IPO (Float) do not have a lower stock volatility, at least not significantly so.

The percentage of total sales coming from the United States seems to increase stock return volatility in the first year, whereas the DebtRatio reduces volatility. This latter result is possibly due to some monitoring done by debt holders who want to make sure that there is enough money to pay the debt, thus resulting in projects that have more stable cash flows. Another 
possibility is that creditors accept to lend money only to those firms that have stable cash flows in the first place.

Finally, when the dependent variable is the market-adjusted quasi-Sharpe ratios (Specifications 3, 4 and 5), the results are still sensibly similar to the results presented in Panel E of Table IV, again suggesting that the selection bias, if it exists, is relatively small and economically inconsequential. Interestingly, the results are still strong when $L n_{-} R O L$ is used (Specification 3), but not when Rate-on-line is used (Specification 4). A possible explanation is that there is some non-linearity in the impact of the rate-on-line that is not picked up by the variable in itself. Specification 5 tests this non-linear hypothesis of the impact of Rate-on-line on the market-adjusted quasi-Sharpe ratio. Results are again in line with the paper's main hypothesis that insurance companies have information that should be valuable to market participants since the rate-on-line of the firms that purchase D\&O liability insurance protection to protect their managers against costly lawsuits appear to have a significant predictive power on the risk-return profiles of firms in the first year post-IPO.

The message that we can take home when we control for the bias associated with the possible difference between firms that purchase D\&O insurance and firms that do not is consistent with the main message of the paper: D\&O insurers appear able to anticipate the riskreturn profile of public firms in their first year of trading. Consequently, consistent with the paper's main hypothesis, the higher is the price of insurance per unit of coverage, the lower will be the total stock return in the first year post-IPO, the higher will be the stock return volatility 
and the lower will be the quasi-Sharpe ratio of the firm, even after controlling for the potential bias associated with the decision to purchase insurance or not

\subsection{Simultaneous (feedback) effects of risk and return}

A second robustness check that is important to conduct is to see what happens if the stock market risk and return are jointly determined and that each feedbacks into the other. For instance, a security that has zero return on every day will have zero volatility. I will therefore modify the econometric models to estimate simultaneously the total stock market returns of the securities and their volatility in the first year post-IPO. The simultaneous regression results using In_ROL as the main independent variable appear in Panel A of Table VII, whereas the results using Rate-on-line appears in Panel $\mathrm{B}$. The econometric technique used in Table VII is either a two-stage or three-stage least square regression to make sure that the results presented thus far are not due to a misspecification of the econometric model. The only difference between Specifications 2 and 3 in both panels is that the year fixed effect is not included in the stock return regression of Specification 3.

[INSERT PANel A of TABle VII about here]

[INSERT PANel B of TABle VII ABout here]

As it is clearly apparent in both panels, the simultaneous equation approach (whether through a two-stage least-square as in Specifications 1 of each panel or a three-stage leastsquare as in Specifications 2 and 3 of each panel) does not alter the main message of the paper: The premium per unit of coverage is a good predictor of the first years' total stock return and 
volatility. Indeed, results in both panels show that the price-to-coverage ratio is positively associated with volatility and negatively associated with returns.

With respect to the control variables, firm size at the time of the IPO (LnMVE_IPO) still has a negative impact on stock market volatility in all model specifications in both panels, and so does the incorporation as an income trust (ITCE) and the debt ratio (DebtRatio). The percentage of sales in the United States is also still significantly positive in explaining Volatility. In terms of the significant impact of independent variables on returns, only the ratio of IPO fees to the market value of equity (IPOfeerat) and Float are significant at the usual levels, but only if we include a time fixed effect in the regression. Interestingly, when the time fixed effect is not included in the regression, it seems that only the premium-to-coverage ratio (however it is measured) has any power in explaining the stock return in the first year.

The results in Table VIII combine both the correction for the selection bias (is a firm insured or not) and the simultaneity of the risk-return relationship in the firms' first year of public life post-IPO. To do so, the regressions include as an explanatory variable the inverse-Mills ratio (MillsRatio) obtained from a first stage regression ${ }^{15}$ on the probability of being insured.

\section{[INSERT TABLE VIII ABOUT HERE]}

As we see, the main message of the paper remains valid. As before, controlling for the selection bias does not seem to alter the results much so that the economic impact of the

\footnotetext{
${ }^{15}$ The regression used to calculate MillsRatio is the same regression as the one used the first stage of the Heckman two-step analysis in Table VI.
} 
independent variables in Table VIII is sensibly the same as in Table VII (as was the case when we compared the results of Table VI with those of Table IV).

\subsection{Information availability}

In Table IX, I present a summary of the previous results, but with a dataset limited to those firms that did not reveal any information related to the D\&O insurance rate-on-line in the IPO prospectus. This further restriction on the data results in the deletion of approximately 15 firms compared to the results presented in Table IV. The reason behind this analysis is to see if my results are due to a subset of firms for which all information related to the D\&O insurance policy was incorporated by the market. Panel A of Table IX presents regression results using the full model to explain first year returns, first year excess return and stock market volatility in the first year. As we see, the results are very close those I presented before so that the negative and significant relationship between the rate-on-line (and the log of the rate-on-line) and the return in the first year post-IPO remains even by removing the 15 -odd firms that revealed their rateon-line in their IPO prospectus. The same can be said about excess returns and stock volatility.

\section{[INSERT PANEl A OF TABle IX ABOUt here]}

Panel B of Table IX presents the regression results when we suppose that the investment bankers incorporated all the public information in the offer price. Again the results tell the same type of story so that the ratio of D\&O liability insurance premium to the D\&O liability coverage appears to have predictive power for the return in the first year of operations post-IPO, but a bit less so when we examine market volatility. 
[INSERT PANEL B OF TABLE IX ABOUt here]

In Panel $\mathrm{C}$ of Table IX, the regression tries to explain the return past the first day. In other words, if we suppose that the market incorporates all the information available in the first day of trading, no information that was available prior to the first day should have any power in predicting returns in the year after the first day. It seems, however, that the return in the first year after the first day is again negatively related to the rate-on-line, whichever way it is measured. The predictive power of the rate-on-line remains quite strong whether we measure the net of first day return as (first year - first day), in the top half of Panel C, or as ( $1+$ first year) / $(1+$ first day $)$ in the bottom half. Results hold whether we use all available data points (Specifications 1 though 4 in both halves of Panel C) or only restrict the analysis to those firms that did not report the rate-on-line in the IPO prospectus (Specifications 5 though 8).

\section{[Insert Panel C of TABle IX about here]}

\subsection{Summary of the robustness checks}

The general conclusion that follows the robustness section of the paper is that the main message of the paper is supported using many different econometric model. It is therefore reasonable to conclude that there is ample evidence to suggest that the price of D\&O insurance per unit of coverage is a good predictor of future stock returns and volatility in the first year of life post-IPO. Indeed, the greater is the D\&O liability insurance premium per dollar of coverage, the lower will be the total stock return, the lower will be the market-adjusted stock return, the 
higher will be the stock return volatility and the lower will be the return-to-volatility ratio. These results are robust enough to safely conclude that hypothesis $\mathrm{H} 1_{0}$ can be rejected.

\section{Discussion and conclusion}

The primary objective of this paper was to examine whether insurers, that provide firms and their managers with protection against the risk of litigation, have access to information that could be valuable to investors at the time of the firms' initial public offering. More precisely, firms that seek to protect their managers against costly liability lawsuits may purchase protection from insurers that examine each firm's governance structure, organizational processes and its "character and culture" to arrive at a premium that reflects the firm's risk of lawsuits. Even though this audit is performed prior to the IPO date, investors learn this information much after, typically right after the first year of operations.

Whenever insurers decide to provide coverage to any policyholder (and this is true whatever the type of insurance that is sold), they assess the potential probability and severity of the possible claim or claims they could potentially be asked to pay. D\&O insurance claims are generally related to lawsuits brought against the firm's managers by shareholders or other stakeholders. Intuitively it is easy to imagine that lawsuits are more frequent when the stock has performed poorly, and that a lawsuit's severity is greater when volatility is higher. Consequently, insurers that sell D\&O insurance must use an audit technology (known as risk underwriting in the insurance industry) that yields a higher price of insurance when the expected loss is greater, whether this is due to a higher frequency of losses (i.e., lower stock returns) or a higher severity of lawsuits (higher stock volatility). The main results of this paper 
confirm this view of the D\&O insurance world. More to the point, I find that firms that pay a high price for their directors' and officers' liability insurance coverage tend to underperform in their first year since they are more likely to have a lower stock return and a higher volatility.

These results lend support to the underlying story that D\&O liability insurers have information about the internal structure of soon-to-be public firms that other investors do not have. Lawsuits are more likely to occur when returns are low and the volatility is high (the downside risk is greater). As a result, when insurers decide to insure a firm's managers against lawsuits brought against them as representatives of the corporation, they assess the potential probability and severity of such lawsuits, which should be related to the future return and volatility of the stock price. Consequently, D\&O insurers have had to develop an audit technology (underwriting skill) such that firms that face a high probability and severity of a costly lawsuit are required to pay a higher price of insurance per dollar of coverage.

It therefore appears that D\&O insurance can act as an alternative to governance indices. Since lawsuits against corporate directors are potentially very expensive, insurers have a monetary incentive to assess properly the amount of risk they are assuming. As a result insurers have a direct incentive to measure this liability risk as it impacts the potential cost of litigation (see Core, 2000, and Baker and Griffith, 2008). Consequently, the ratio of D\&O insurance premium to $D \& O$ insurance coverage offers a measure of the governance and litigation risk that a firm faces; a measure which, if underestimated by the insurance company, will lead to unexpected losses by the entity that issues the measure. 
Unfortunately for American investors, the information related to the purchase of D\&O insurance is usually not available in the United States (see Griffith, 2006). And even in cases where some information is available, as in the state of New York (see Linck et al., 2009), only the premium information is given, which is insufficient to draw any reasonable conclusion on the firm's risk.

The results in this paper suggest that mandating the revelation of basic D\&O insurance information (premium and coverage) could be valuable to investors since it would provide them with an unbiased signal about a firm's risk of litigation against its directors and officers, perhaps because of some managerial mishaps. As the vast majority of Canadian and American corporations purchase liability insurance on behalf of their directors and officers (see the different Towers-Watson surveys), wouldn't it be efficient to have access to this risk measure? One must be wary to make such a leap to large U.S. listed firms, however, since the results in the current paper relate only to the case of small Canadian firms that became public through an initial public offering. Nevertheless, the question is relevant and timely given the time and energy that investors and regulators devote to governance issues. 


\section{References}

Adams R., B.E. Hermalin and M.S. Weisbach (2010). The Role of Board of Directors in Corporate Governance: A Conceptual Framework and Survey. Journal of Economic Literature, 48: 58-107.

Bajaj, M., S. Mazumdar and A. Sarin (2000). Securities class action settlements: an empirical analysis. Working Paper, University of California, Berkeley. Available at SSRN: http://ssrn.com/abstract=258027.

Baker, T. and S.J. Griffith (2007a). Predicting Corporate Governance Risk: Evidence from the Directors' and Officers' Liability Insurance Market. University of Chicago Law Review, 74: 1-58.

Baker, T. and S.J. Griffith (2007b). The Missing Monitor in Corporate Governance: The Directors' and Officers' Liability Insurer. Georgetown Law Journal, 95: .

Baker, T. and S.J. Griffith (2008). How the Merits Matter: Directors' and Officers' Insurance and Securities Settlements. University of Pennsy/vania Law Review, 157: 755-832.

Bebchuk, L.A., A. Cohen and A. Ferrell (2009). What Matters in Corporate Governance? Review of Financial Studies, 22: 783-827.

Bebchuk, L. A. and A. Hamdani (2009). The Elusive Quest for Global Governance Standards. University of Pennsylvania Law Review, 157 (4): 1263-1317.

Bebchuk L.A. and M.S. Weisbach (2010). The State of Corporate Governance Research. Review of Financial Studies, 23: 939-961.

Bhagat S. and B. Bolton (2008). Corporate Governance and Firm Performance. Journal of Corporate Finance, 14: 257-273.

Bhagat, S., J.A. Brickley and J.L. Coles (1987). Managerial Indemnification and Liability Insurance: The Effect on Shareholder Wealth. Journal of Risk and Insurance, 54: 721-736.

Beatty, R.P and J.R. Ritter (1986). Investment bank reputation and the underpricing of initial public offerings. Journal of Financial Economics 15: 213-232.

Blades, J. (2006). A different outlook: D\&O underwriters are putting companies under more scrutiny than in the past. Best's Review, September 2006, p.107-108.

Boyer, M.M. (2003). Directors' and Officers' Insurance and Shareholders' Protection. CIRANO Scientific Series, No.2003s-64 (http://www.cirano.qc.ca/pdf/publication/2003s-64.pdf).

Boyer, M.M. and L.H. Stern (2012). Is Corporate Governance Risk Valued? Evidence from Directors' and Officers' Insurance. Journal of Corporate Finance 18: 349-372. 
Boyer, M.M., and S. Tennyson (2008). Directors' and Officers' Liability Insurance, Corporate Risk and Risk Taking: New Panel Data Evidence on the Role of Directors' and Officers' Liability Insurance. ARIA 2008 meeting, Portland (OR).

Cao, Z. and G.S. Narayanamoorthy (2011). The Effect of Litigation Risk on Management Earnings Forecasts. Contemporary Accounting Research, 28: 125-173.

Chalmers, J.M.R., L.Y. Dann and J. Harford (2002). Managerial Opportunism? Evidence from Directors' and Officers' Insurance Purchases. Journal of Finance, 57: 609-639.

Clarkson, P. and D. Simunic (1994). The Association between Audit Quality, Retained Ownership and Firm-Specific Risk in United States vs. Canadian IPO markets. Journal of Accounting and Economics, 17: 207-228.

Core, J. E. (1997). On the Corporate Demand for Directors' and Officers' Insurance. Journal of Risk and Insurance, 64: 63-87.

Core, J.E. (2000). The Directors' and Officers' Insurance Premium: An Outside Assessment of the Quality of Corporate Governance. Journal of Law, Economics and Organization, 16: 449-477.

Fier, S., J. Gable, K.A. McCullough and N. Mansfield (2010). The Directors and Officers Insurance Marketplace: An Empirical Examination of Supply and Demand in Uncertain Times. WRIEC 2010 meeting, Singapore.

Gillan, S. and C. Panasian (2009). Reassessing what matters in Corporate Governance: Evidence from the Market for Directors' and Officers' Liability Insurance. FMA 2009 meeting Reno (NV).

Gillen, M., 2005. Income Trust Unitholder Liability: Risks and Legislative Response. Canadian Business Law Journal 42: 325-345.

Griffith, S.J. (2006). Unleashing a Gatekeeper: Why the SEC Should Mandate Disclosure of Details Concerning Directors' and Officers' Liability Insurance Policy. University of Pennsylvania Law Review, 154: 1147-1208.

Gutiérrez, M. (2003). An Economic Analysis of Corporate Directors' Fiduciary Duties. Rand Journal of Economics, 34: 516-535.

Heckman, J. (1979). Sample Selection Bias as a Specification Error. Econometrica, 47: 153-161.

Holderness, C.G. (1990). Liability Insurers as Corporate Monitors. International Review of Law and Economics, 10: $115-129$.

Huson, M.R. and F. Pazzaglia (2007). Choice of Organizational Form as a Trade-Off between Fit and Market Timing. Available at SSRN: http://ssrn.com/abstract=970268. 
Kalchev, G. (2004). The Demand for Directors' and Officers' Liability Insurance by US Public Companies. Available at SSRN: http://ssrn.com/abstract=565183.

Knepper, W. and D.A. Bailey (1998). Liability of Corporate Officers \& Directors, Seventh Edition, Matthew Bender edition.

Lin, C., M.S. Officer and H. Zou (2011). Directors' and officers' liability insurance and acquisition outcomes. Journal of Financial Economics, 102: 507-525.

Linck, J.S, J.M. Netter and T. Yang (2009). The Effects and Unintended Consequences of the Sarbanes-Oxley Act on the Supply and Demand for Directors. The Review of Financial Studies, 22(8): 3287-3328.

Maddala, G.S. (1983). Limited Dependent and Qualitative Variables in Econometrics, Cambridge.

McTier, B.C. and J.K. Wald (2011). The Causes and Consequences of Securities Class Action Litigation. Journal of Corporate Finance, 17: 649-665.

O'Sullivan, N. (1997). Insuring the Agents: The Role of Directors' and Officers' Insurance in Corporate Governance. Journal of Risk and Insurance, 64: 545-556.

Park Wynn, J. (2008). Legal Liability Coverage and Voluntary Disclosure. The Accounting Review, 83: 1639-1669.

Rees, R., D. Radulescu and P. Egger (2011). Corporate Governance and Managerial Incentives: Evidence from the Market for D\&O Insurance. Working paper, ETH Zurich

Ritter, J. (1984). The 'hot issue' market of 1980. Journal of Business 57: 215-240.

Ritter, J. (1987). The costs of going public. Journal of Financial Economics 19: 269-282.

Ritter, J. (1991). The long-run performance of initial public offerings. Journal of Finance 46: 3-27.

Rose, P. (2007). The Corporate Governance Industry. Journal of Corporation Law, 32(4)

Wintoki M.B., J.S. Linck and J.M. Netter (2012). Endogeneity and the Dynamics of Corporate Governance. Journal of Financial Economics (In Press). 